\title{
COULD THE SERBIAN BANKING SECTOR BE IMPROVED BY INTRODUCING, TROUGH NATIONAL LEGISLATION, THE PRINCIPLES AND MECHANISMS OF THE EU BANKING UNION
}

\begin{abstract}
The answer is Yes!
The Government and the Parliament of Serbia can prepare and pass any law necessary to improve the economic system of the country.

Monetary policy in the EU and the functioning of the banking sector is under control of the European Central Bank (ECB) and it should be in the prerogatives of the Central bank in Serbia as well. The Central bank creates appropriate policies concerning most issues of general monetary policy. Those policies should be reflected in the activities of the whole banking sector. That would be possible if all banks followed and implemented the monetary policy of the central bank. For that, they would have to fulfill all the conditions concerning the structure of their capital and balance sheet, to keep their license. In order to introduce and maintain those criteria, the EU established its Baking union.
\end{abstract}

Key words: European banking union, bailout and closure of banks, guaranty of deposits

The necessary conditions for the building of the EU Banking union implied the adoption of a single rulebook for the European financial market and a

1) Single Supervisory Mechanism (SSM),a

2) Single Resolution Mechanism, with a Single Resolution Fund, and a fiscal backstop and

3) Harmonization of the Deposit Guarantee Schemes.(1)

In the meantime we will see the first results of what has been accepted by the European Parliament recently. It is expected that the above mentioned important elements of the Banking union will start to be implemented soon.

Banks received a 200 plus pages book for the preparation of their submission to the ECB and, later, for the stress test they will have to undergo. State governments are preparing to help in cases of recapitalization or merger.

Oskar Kovač, Professor emeritus, Faculty of International Economy, Megatrend University, Belgrade, e-mail: okovac@megatrend.edu.rs

** Professor Dejan Šoškić, PhD, Faculty of Economics, University of Belgrade, e-mail: soskic@ekof.bg.ac.rs 
This exercise will involve not only banks in the EMU member states, but indirectly, by showing the EMU area banks' connections with the banks in the EMU nonmember states, almost the entire European banking community.

After a number of difficult years, the interest to join and maintain the EU and EMU is still significant. That would not be so if there were no economic, cultural and national safety related benefits (2). The results of relevant research given in the work under (2) in the literature list seem to convey a clearly positive answer. The authors analyze relevant factors and data from the 1980 and 2004 enlargements, concerning benefits of the EU membership and their calculations show a gain of some $12 \%$ of per capita GDP.

All research results and the main features of the European banking system lead to an agreement concerning the creation of the Banking union of the EU. To transform the nationally created and guided banking systems into a single European banking system, all banks of the EU member countries have to be inspected, and if they pass a positive decision of the Single supervisory mechanism (the ECB), be accepted into the European banking union. Within the union, if it becomes necessary, any member of the Banking union may ask for help and recapitalization from the EMU`s Single Resolution Fund. Their depositors will be covered (for deposits up to 100.000 euros) by a harmonized and improved Deposit Guarantee Scheme.

\section{The Single Supervisory Mechanism}

The regulations establishing the Single Supervisory Mechanism were adopted on 15, October 2013. In December the Council appointed the first chairperson of the supervisory board of the ECB. The single supervisory board will have direct oversight of the banks in the euro area and non-euro zone member states that choose to participate.

The European Central bank will have direct oversight of 130 banks in the euro area or $85 \%$ of the whole Banking union of the EU. The comprehensive assessment including the asset quality review of those banks will begin soon. That will be followed by a stress test of banks in coordination of the European Banking Authority.

The EU banking community is anticipating some future consequences of the establishment of the Banking union. Some banks have already closed down. According to the European central bank data, the number of banks in the euro zone fell by almost $4 \%$ in 2013. There were 6.790 monetary-financial institutions based in the euro area at the start of 2014 compared with 7,069 a year before. More than 3.066 monetary-financial institutions have fallen since the launch of the euro in 1999.(3). 
The forthcoming ECB review forces banks in some countries to write off bad loans and clean up their balance sheets in general. Some banks are increasing lending ahead of the ECB stress tests, probably also because the ECB will publish the stress tests of Europe's biggest banks before it takes over the supervision of all banks. While waiting for the new regulation, banks have been holding back lending in order to look good at the stress test. The ECB might want to revive credit activity with another sum of the cheap long-term loans (4).

Some bankers expect the ECB stress tests to reignite banking M\&A loans. The ECB asset quality review of more than 120 banks should bring transparency on the quality of their loans and other assets. The initial increase in merger activity is expected to take place within single countries, as weaker companies restructure and accept effective takeovers.

\section{The Single Resolution Mechanism}

The banking union is the latest accepted element of a set of consistent policies and measures to resolve the Euro zone crisis. The necessary conditions to introduce a well functioning banking union lie in that "consistent trinity" (5), deep fiscal and structural reforms within countries, and a rotation of demand that contributes to a more symmetric adjustment across countries.

The Banking union will start to function after the ECB finishes the first round of the single supervisory mechanism, the control of banks capital and their functioning. The legal basis of the Single Resolution Mechanism was founded in the law, which was also passed on 15, April 2014, with an overwhelming majority of the members of the Parliament.

The creation of the single resolution mechanism (SRM) of failing banks with a central decision-making board and a single resolution fund will ensure that resolution decisions across participating member states be taken in a coordinated and effective manner, minimizing negative impacts on financial stability and reducing the dependence of banks on the creditworthiness of sovereigns.

The aim is to ensure the orderly resolution of failing banks without the use of taxpayers' money. This will involve both a systematic recourse to the bail in of shareholders and creditors, in line with the bank recovery and resolution directive agreed in December 2013, and the possible recourse to a single fund fully financed by banks.

The SSM that entered into force in November 2013, will cover all banks established in the euro area and in other EU member states that choose to participate (6).

A single resolution board will, upon the notification of the ECB that a bank is failing or likely to fail, adopt a resolution scheme placing the bank into resolution. It will determine the application of a resolution tool and the use of the single 
resolution fund. The resolution scheme will enter into force within 24 hours of its approval by the board. The board will be responsible for the planning and resolution phases of the cross-border banks and those directly supervised by the $\mathrm{ECB}$, while national resolution authorities will be responsible for all other banks.

The Single resolution fund will be built up over a period of eight years to reach a target level of at least $1 \%$ of the covered deposits amount of all credit institutions authorized in all the participating member states. It is estimated that this will amount to about 55 billion euros. Participating member states also intend to approve a future intergovernmental agreement on the transfer and mutualisation of contributions to the Single resolution fund. It is planned for the contributions by banks raised at national level to be transferred to the SRF and be initially held there in national compartments. There will be a mutualisation of those contributions to the Single resolution fund. That will start with $40 \%$ in the first year and a further $20 \%$ in the second year, and continue over the subsequent six years until the SRF is fully mutualized.

Provisions on the preparation of resolution planning with national resolution authorities will apply from January 1, 2015. Provisions relating to resolution instruments, including the bail in of shareholders and creditors will apply from January 2016. Altogether, the establishment of the European Banking union is an important and respectable achievement. Still, it would be irresponsible to argue that from now on there will be no serious issues and that it will not to be difficult for those banks to contribute to a much greater resolution fund.

SO, COULD SERBIA IMPROVE ITS MONETARY AND BANKING SISTEM BY USING THE PRINCIPLES, INSTITUTIONS AND INSTRUMENTS OF THE EU BANKING UNION?

The Banking Union (BU) is a natural step forward in development of Economic and Monetary Union (EMU). One could argue that the BU is a crucial pillar of EMU alongside Economic Union, Fiscal Union, and Political Union (7), and that its development, in the eyes of many, was long overdue.

Financial crisis of 2007/2008 occurred within the EU that had 27 different regulatory systems for banks, no tools to deal with large cross-border banks, and a single backstop for banking losses with national budgets. Banks were "European in life and national in death". The entire national perspective concerning bank regulation, supervision, and resolution was not sufficient for the posed challenge. No Euro zone crises management framework had been put in place to support national resolution capacities. Such a framework was prone to large fiscal burdens on national government levels ${ }^{1}(10)$, and vicious circles

Approved state aid in the EU (recapitalization and asset relief measures) between October 2008 and December 2012 amounted to 591,9 billion Euros or 4,6\% of EU 2012 GDP. With 
between banks and national finances. As an aftermath, sovereign debt crises within a Euro zone came as no surprise.

The problem of sovereign debt crises in Euro zone was predominantly influenced by bank-sovereign interdependence. However, there are only several possible remedies to this problem. The first is to allow the ECB to lend to sovereigns. This solution is in clear breach of the no-monetary financing of the EU Treaty. The second option is to have co-responsibility for public debt in the Euro zone i.e. a fiscal union. This solution is not yet politically available. The third remaining option is to have a financial union, and in the case of Euro zone finance, where the bank credit is a predominant financial instrument, that meant the creation of the Banking union. In other words, it is not possible to have no co-responsibility for public debt, strict no-monetary financing, and no bank-sovereign interdependence. The current Euro zone structure (Figure 1.) had to change towards the creation of the BU in order to disentangle the vicious circle of bad bank balance sheets and bad public finance. One can see that this as an available move in a necessary direction, which can be implemented even before the Fiscal union is constructed in a way politically acceptable for all the Euro zone countries.

Despite the fact that BU is a project specifically designed for the EMU and EU countries, there are several very important elements of this project that could be important for, and implemented within the countries outside the EU, including Serbia.

Figure 1: The new trilemma ${ }^{2}$

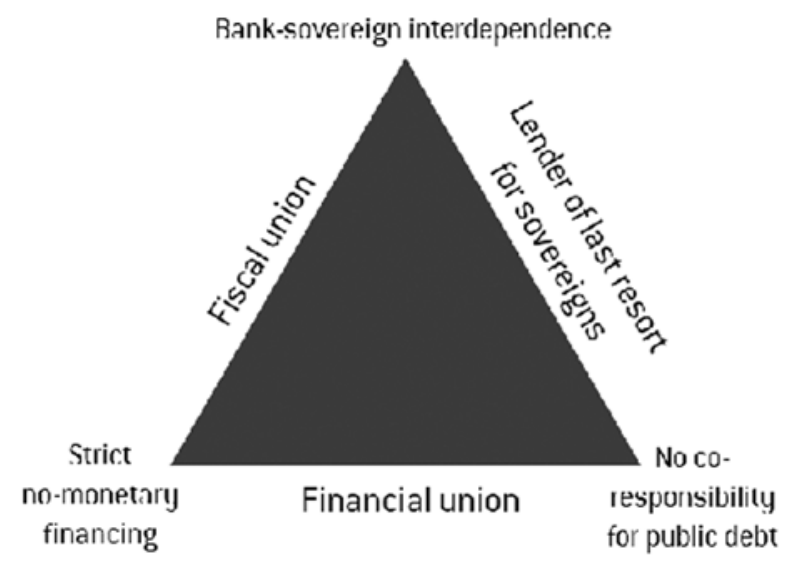

Source: Pisani-Ferry, 2012, pp.8 (8)

guarantees the figure rises to 1.600 billion Euros or $13 \%$ of EU GDP for the period 20082010 only.

2 Refereeing to the old trilemma of Mundell-Fleming model that you cannot have a flexible exchange rate, free capital flows, and independent monetary policy at the same time. 
Whenever you have significant leverage and/or non-performing loans (NPLs) alongside a substantial exposure of banks to sovereigns, economic contraction can produce a negative spiral between worsening bank balance sheets and erosion of national government financial position (Figure 2.). This is reliant on a premise that the central bank is not allowed to finance the government (or provide equity financing for the failing banks) and that the national government is the only backstop for failing systemic banks. Since that is the case in most (both the EU and non EU) countries, the lessons from the sovereign debt crises in Europe and the creation of BU can prove to have valuable guidelines for non EU countries like Serbia.

Figure 2: Vicious circle between banks and national finances

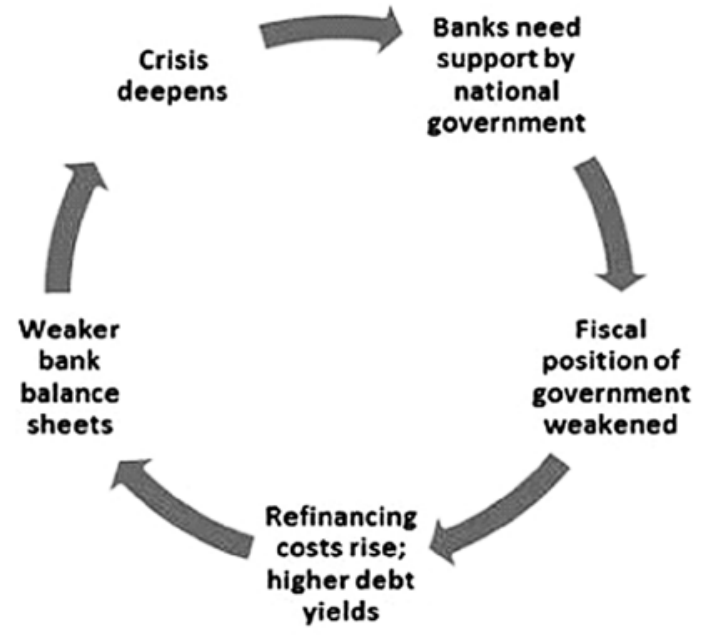

Source: European Commission 2014, (9).

The creation of the BU relies on the will to make banks stronger and more immune to shocks. This is a basic principle of creation of a more sound financial system, less prone to the exposure of the losses it cannot sustain. This point has a regulatory and a supervisory aspect, and they are both applicable in Serbia.

First, regulatory aspect relates to the implementation of Basel III standards (which are already implemented in the EU through CRD4). The implementation of these standards will provide more quality capital base and liquidity for the banks and insure their strength and immunity to shocks. This is a very important element in providing more loss absorption capacity on the side of the banks, and less risk of additional government expenditures in case of further bank insolvencies. National bank of Serbia (NBS) has implemented Basel II standards in 2011, and also plans to implement Basel III standards, but not earlier than 
2016. Since the banking sector of Serbia is burdened with relatively high levels of NPLs, and since recent bank failures have caused substantial burden for an already fragile fiscal position of the country, it might be wise to consider an earlier adoption of the Basel III standards in Serbia. These standards represent a significant portion of the so-called Single rule book of the BU.

Second, the supervisory aspect relies on increasing the supervisory capacity of an existing regulator. In case of $\mathrm{BU}$, it includes the conduct of screening of the bank balance sheets and implementing stress tests that are realistic for the banks to endure in case of severe financial crises. As in the case of $\mathrm{BU}$, where prior to the ECB engagement as a single supervisor for the whole EMU, thorough screening and stress testing is underway to expose the strengths and weaknesses of the banking sector, Serbian banking sector should be submitted to the similar process to create a realistic vision of the risks and weaknesses to be addressed preemptively. Therefore, increasing the institutional capacity and uncovering realistic facts in the process of BU creation are needed and desirable in the countries like Serbia as well.

Third, very important aspect of the BU framework is the creation of a more effective early intervention system on the side of a supervisor. The same is sorely needed in Serbia. Hand in hand with the need to increase the capacity of NBS to detect problems in the banking sector early, the supervisor needs to have powers to react to this findings without delay i.e. long before capital and liquidity parameters go below the required levels, and sometimes, beyond realistic and swift repair. As in the case of $\mathrm{BU}$, these may include demanding recovery plans from the banks, dismissal of the management and the appointment of a special manager, waiver of the distribution of dividends and bonuses, forceful reduction of certain exposures, increase in capital, and mandatory changes to legal or corporate structures of the bank. All of these measures foreseen by the $\mathrm{BU}$ to be delegated to the supervisor are eligible for being potentially implemented in Serbia as well.

Finally, BU introduces a very important principal of prohibiting tax payers' money to be used to finance bank bailouts. It is especially after recent experiences in Serbia, and its fragile fiscal position, that this principal deserves to be thoroughly analyzed and implemented. The 'too-big-to-fail' idea should be a thing of the past. Alongside stricter regulation, better supervision and preemptive measures, orderly resolution of insolvent banks should be the final important element of the BU principles that could be implemented in Serbia. The clear system of private bail-ins, and bank funded resolution fund is a desperately needed improvement of the banking system, especially for the countries like Serbia, with serious fiscal challenges. For the banks which prove to be unviable, winding down of their operations and orderly resolution without stress implications to the rest of financial system is vital. In the past couple of years some lessons have been learned in Serbia from several bank failures, but there is substantial room for the 
resolution process improvement so that it could be much less expensive for the taxpayers and yet without financial stability consequences.

As we can see, Banking Union has been enacted as a project designed to help overcome the problems of financial crises in the EU, and with a goal to establish a more robust financial system capable of substantially decreasing the risk of future taxpayers' money involvement in banking bailouts. However, despite the fact that such a project has been developed to address the specific problems and issues in the Euro zone, it has also developed universal principles and ideas for improvements in national and regional financial system throughout the world. Serbia, as a developing nation in South East Europe, can also benefit from a number of very useful guidelines and specific measures that can be drawn from the principles and the mechanisms of the EU Banking Union.

\section{Literature}

- Merler,S. Wolf G.B. Ending Uncertainty: Recapitalization under European Central Bank supervision, Bruegel Policy Contribution, December, 2011.

- Campos, N.F.,Coricelly,F.,Moretti,L., How much do countries benefit from membership in the European union? http:// voxeu.org. article.

- http://reuters.com//assets/print aid.

- Buti,M.Delivering the Eurozone "Consistent trinity", http/www voxeu.org/article.

- Council of the European Union, presse./192.

- Council of the European Union, press releases, passim

- Draghi, Mario, 2013, "The role of monetary policy in addressing the crisis on the euro area", Speech by Mario Draghi, President of the ECB, at the "Room for Discussion" of the Study Association SEFA and the Faculty of Economics and Business, Amsterdam, 15 April 2013, http:// www.ecb.europa.eu/press/key/date/2013/html/sp130415.en.html

- Pisani-Ferry, Jean, 2012, The Euro Crisis and the New Impossible Trinity, Bruegel Policy Contribution, January 2012, http://www.bruegel.org/ publications/publication-detail/publication/674-the-euro-crisis-and-the-new-impossible-trinity/

- European Commission, 2014, "Banking union: restoring financial stability in the Eurozone", Memo, Brussels, 15 April 2014, http://europa.eu/ rapid/press-release_MEMO-14-294_en.htm

- European Commission, 2013, “State aid: Commission's new on-line state aid benchmarking tool shows less aid to banks", Press Release, Brussels, 20 December 2013, http://europa.eu/rapid/press-release_IP-13-1301_en.htm

Paper received: October $17^{\text {th }}, 2014$

Rad primljen: 17. oktobar 2014.

Approved for publication: October $28^{\text {th }}, 2014$ Odobren za štampu: 28. oktobar 2014. 


\section{Profesor emeritus, dr Oskar Kovač,}

Fakultet za medjunarodnu ekonomiju

Megatrend univerzitet, Beograd

Profesor dr Dejan Šoškić,

Ekonomsdki fakultet, Univerzitet u Beogradu

\section{MOŽE LI SE BANKARSKI SEKTOR PRIVREDE SRBIJE UNAPREDITI UVODJENJEM, PUTEM DOMAĆIH PROPISA, PRINCIPA I MEHANIZAMA BANKARSKE UNIJE EVROPSKE UNIJE}

\section{S a ž e t a k}

Parlament i Evropska komisija, sasvim pri kraju svog prethodnog mandata, doneli su propise sa zakonskom snagom, kojima je stvorena bankarska unija Evropske unije.

Stvaranjem te unije se pod direktnu kontrolu Centralne banke Evropske unije stavlja velika vecina banaka koje rade u vise zemalja EU. Banke ce poslovati po istim propisima za funkcionisanje evropskog finansijskog trzista. To je funkcionisanje u okviru jedinstvenog mehanizma nadzora, jedinstvenog mehanizma ozdravljenja banaka (sredstvima specijalnih fondova za ozdravljenje) ili njihovog organizovanog gasenja. Posebno ce se uniformno regulisati ozbiljna zastita depozita u bankama. Za sada se blagovremeno ostvaruju svi navedeni elementi izgradnje Bankarske unije.

Istrazivanja u ovom radu pokazuju da Srbija moze svojim zakonima da stvori sopstvenu bankarsku uniju koja bi mogla da obezbedi dobro funkcionisanje bankarskog sektora i finanijskih trzista. Ovo utoliko pre sto medju bankama koje posluju u Srbiji ima izrazito mnogo onih ciji su osnivaci u Ervopskoj uniji koji vec posluju u Evropskoj bankarskoj uniji.

Ključne reči: bankarska unija EU, sanacija banaka, gasenje banaka, garantovanje depozita. Bankarska unija za Srbiju 
